\title{
ADDRESS BY THE LOCAL ORGANIZING COMMITTEE
}

Dear colleagues,

It is a pleasure to welcome all of you to the 212th Symposium of the International Astronomical Union and to speak on behalf of the Local Organizing Committee. It has been a long way since the last meeting on massive and Wolf-Rayet stars held at Puerto Vallarta, so well organized by our Mexican friends. We hope that, in this new occasion, we do not disappoint you and that the symposium will fulfill your expectations. All our efforts are in this direction. We have counted with very efficient people in the LOC, specially the secretaries of the research division of the Instituto de Astrofísica de Canarias (IAC): Tanja, Eva and Judith. They are the true pillars of the organization. Also, we have been very fortunate of having the unconditional help of the staff and personnel of the computer center (Servicios Informáticos Comunes) of the IAC.

We are deeply grateful to several institutions for their financial and organizing support: the International Astronomical Union, the Spanish Ministry of Science and Technology, the Autonomous Government of the Canary Islands, the Government of the Island of Lanzarote, the City Council of Teguise, the University of La Laguna, Iberia Airlines, and the DISA Oil Corporation.

Recall that just last Friday, June 22nd, was the summer solstice. Of course, all of you know that this is a significant date, astronomically speaking. Yesterday, June 23rd, was the eve of Saint John's Day, and popular bonfires were celebrated at night time in Lanzarote, the whole archipelago and many parts of the Mediterranean. These are ancient festivities related to the fertility to the earth, the animals and the human beings. The ancient people of Lanzarote and the whole Canary Islands, those living here before the Castillian conquest, were worshippers of the sun. They inhabited the islands at the beginning of the Christian Era and came from the splendid lands of North Africa.

Many early writers from conquest times tell us, that the ancient Canarians worshipped the sun, the moon and other celestial bodies, and that the summer solstice was an important moment of the year. In fact, the historian Marín de Cubas tells us in his chronicle: "The ancient Canarians counted their year by lunations of 29 days from the new moon. They began the year in summer, at the first conjunction between the sun and the moon, after the sun enters the constellation of Cancer at June 21st; they made great dances and festivals for nine consecutive days, having gathered their harvests. They made scratches on tables, walls or stones, calling tara and tarja, for the memory of its meaning ..." Let's celebrate this ancient Canarian new year talking about - or even worshipping - our massive stars, but do not forget to enjoy yourselves and the friendly people and amazing landscape of this beautiful island.

Thank you very much, and welcome.

César Esteban, chair LOC

Lanzarote, 24 June 2002 